\title{
How Schizophrenia Could be Caused by Cholera \& Ferric Chloride Disease
}

ISSN: 2637-8078

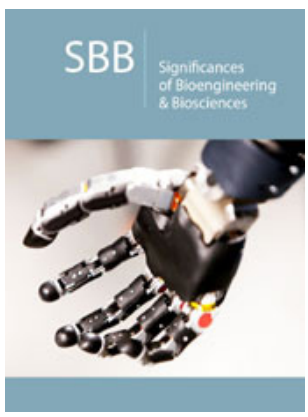

*Corresponding author: Cusack Paul TE, Department of BScE, Canada

Submission: 梅 September 09, 2019

Published: 踚October 09, 2019

Volume 3 - Issue 5

How to cite this article: Cusack Paul TE. How Schizophrenia Could be Caused by Cholera \& Ferric Chloride Disease. Significances Bioeng Biosci.3(5) SBB.000571.2019.

DOI: 10.31031/SBB.2019.03.000571

Copyright@ Cusack Paul TE, This article is distributed under the terms of the Creative Commons Attribution 4.0 International License, which permits unrestricted use and redistribution provided that the original author and source are credited.

\author{
Cusack Paul TE* \\ Department of BScE, Canada
}

\section{Abstract}

In this brief paper, we build upon other papers by this author that had two separate causes for schizophrenia. We combine the findings that point to Ferric Chloride and Cholera as the culprits as the underlying cause of schizophrenia.

Keywords: Schizophrenia; Ferric chloride disease; Dehydration; Alcohol

\section{Introduction}

Cholera produces dehydration in its victims. I suspect that the survivors of cholera have their DNA damaged by the bacterium. The Adenine in DNA has a hydroxide ion an alcohol attached. It could be stripped off the cyclohexane to join to the Hydrogens from the acid (water is a weak acid) or the DNA itself. Perhaps the Iron replaces the hydrogen on the DNA molecule while Chlorine does the same for the hydroxide ion, the alcohol [1-4]. The damaged adenine has a chlorine and an iron in place of the Hydrogen and Hydroxide (Figure 1).

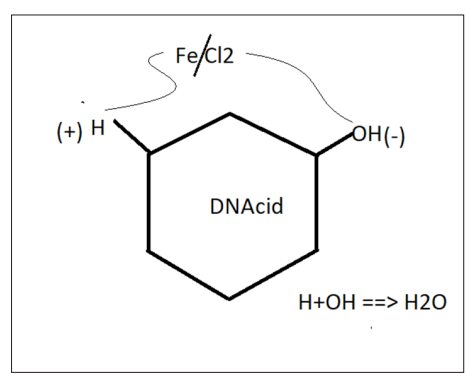

Figure 1: The damaged adenine has a chlorine and an iron in place of the hydrogen and hydroxide.

$$
2 \mathrm{FeCl}_{2}+2 \mathrm{HOH} \rightarrow 2 \mathrm{FeOH}+2 \mathrm{HCl}+\mathrm{Cl}_{2}
$$

Dehydration of Alcohol

$$
\mathrm{C}=\mathrm{C}(\mathrm{H}-\mathrm{OH}) \rightarrow \mathrm{HCl}(\text { ACID CATYLST }) \rightarrow \mathrm{H} \mathrm{OH}(\text { WATER })
$$

\section{Conclusion}

My original thesis had Ferric Chloride $\left(\mathrm{FeCl}_{2}\right)$ as the culprit causing schizophrenia [5,6]. Yet, cholera has a role too. This latest theory explains why iron laden water may lead to schizophrenia. It may also explain why schizophrenia is a northern hemisphere problem viz. Water supply systems using iron piping [7-9].

\section{References}

1. Cusack P (2017) Schizophrenia and its causes: Ferric chloride (Cusack's) disease. Men Health Fam Med 2: 1-2.

2. Cusack P (2017) Mental illness and cholera. Men Health Fam Med 2: 1-2.

3. Cusack P (2017) More on the robust solution for epidemiology: Nineteenth century in Quebec. J Biomet Biostat 8: 1-2. 
4. Cusack P (2017) Cholera, iron and mental illness in nineteenth century. J Biomet Biostat 8: 1-2.

5. Cusack PTE (2017) LSD, caffeine, and cholera: Possible causes of schizophrenia. J Mol Genet Med 11(4): 296.

6. Cusack PTE (2018) Chlorine, creosote and dementia. EC Psychology and Psychiatry 7(1): 11-12.
7. Cusack PTE (2018) SZ and its cause: Ferric chloride disease. PRAS.

8. Cusack PTE (2017) Dehydration: The cause of schizophrenia: Cholera, ferric chloride and caffeine. EC Psychology and Psychiatry 6(2): 89-90.

9. Cusack PTE (2017) More on cholera and schizophrenia: In Mauritius. American Journal of Biometrics and Biostatistics 1(1): 1-2

For possible submissions Click below: 